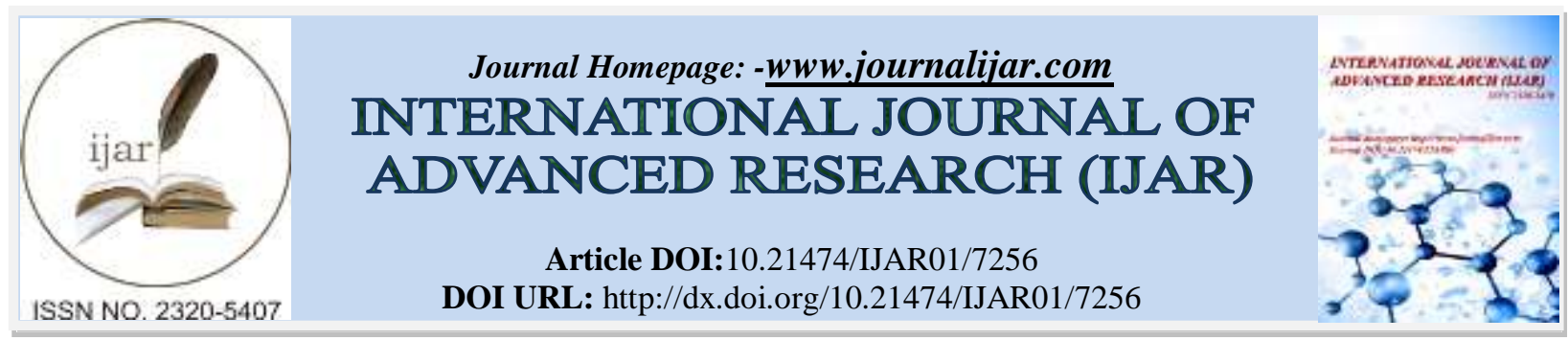

RESEARCH ARTICLE

\title{
FROM POLITICAL ANTHROPOLOGY TO ANTHROPOLOGY OF POLITICS: AN INTRODUCTION.
}

\section{Priti Bhowmick ${ }^{1}$ and Pinaki Dey Mullick ${ }^{2}$.}

1. Junior Research Fellow (UGC-NET), Department of Anthropology, University of Calcutta, 35 Ballygunge Circular Road, Kolkata 700019, West Bengal, India.

2. Assistant Professor, Department of Anthropology, Haldia Government College, Debhog, Purba Medinipur 721657 , West Bengal, India.

\section{Manuscript Info}

Manuscript History

Received: 11 April 2018

Final Accepted: 13 May 2018

Published: June 2018

\section{Keywords:-}

Political Anthropology, Paradox, Classical Anthropology, PostStructuralism, Anthropology of Politics.

\begin{abstract}
The present effort is a compendious review of the theoretical orientations of political anthropology. Authors deliberately unfold the discussion with a paradox between the 'political anthropology' and the 'anthropology of politics' as a key that ought to relate the contemporary multidisciplinary stands of the subfield. It further focuses on the 'troubled history' of the sub-discipline to understand how it intensified sensitivity towards the pervasiveness of the embedded power and politics within the 'everyday' practice. The ubiquitous 'anthropology of politics' essentially prioritizes the increasing politicization of every single anthropological theme which was beyond the matrix of a single review article. So, the present attempt is rather an outline to render the sporadic growth of political anthropology over the century. By focusing on the successive approaches and recent trends authors try to extend the further scope of the interdisciplinary researches on the complexities and challenges of political anthropology within the age of neoliberal globalization.
\end{abstract}

Copy Right, IJAR, 2018,. All rights reserved.

\section{Prelude:-}

Since the gestation, anthropology has had a close affinity with the term 'politics'. In the cue of Aristotle's Politics where he conceptualized human being as essentially and innately a 'political being', the inception of political anthropology within the wing of anthropology was started at first as a project later [re]defined into a specialization/sub-discipline of it (Lewellen, 2003). The main thirst of the political anthropology was to devise a science of the political discourses of Homo politicus (Brennan, 2008) which would comparatively study the forms of political organizations, political leaderships, and differentiated ways of dealing with conflict among the 'stateless' societies. But since the second world war anthropology has become increasingly political, even politicized, exactly in the same period as the established subcategory of the discipline, political anthropology, has faded away, and exactly as many works carried out under this category were either deconstructed or pushed into oblivion-mostly the latter (Thomassen, 2008:263) with a resurgence of anthropology of politics. This paradox resides within the heart of the 'developing history' of anthropology which not only deconstructed the aim, methods and theoretical orientations of the sub-discipline but also rejected the unyielding claim of it being a 'sole science of the political affairs of the primitive societies'. 
This inconsistent, 'troubled history' of the political anthropology ritually posits itself impossible to conceive the what, how, why and where of current political anthropology (Dhakal, 2010:12) which call for a conscious review of the discipline as well as its multiple alliances with other contemporary social and political sciences. In this paper authors try to brief the history and the emerging issues within the sub-discipline in a way that will be discernible to the larger target audiences.

\section{Anthropology And Politics: The Precursors:-}

Though the impetus of 'politics' within the domain of social sciences can be pursued back to Plato, Aristotle, Hobbes, Rousseau, the formal beginning of the study of politics within anthropology had been started with the anthropologists like Tylor, Morgan, Maine, McLennan and other classical evolutionists who had certain direct or indirect propinquity with the domain of law (Salemink, 2003). So, it can be said that anthropology has been critically rooted in legal discourses.

One of the resultant of this association was the seminal work of Henry Maine, Ancient Law (1861), a comparative study on the Indo-European institutions which revealed two convergent evolutionary patterns where societies gradually shift from 'based on status' to 'based on contract' and the social organizations nested on kinship evolved towards the principle of 'local contiguity' which further conformed the base of the collective political action. Maine's concept of kinship as a political organization was further developed in Ancient Society (1877), by Morgan where he emphasized kinship as a primary mode of political interaction in the subsistence economy. Despite of several methodological criticisms, his insights on the concept of common property within the egalitarian societies instigated the phenomenal work of Engels, named The Origin of the Family, Private Property and the State (1972).

The classical evolutionists agreed upon that to some extent every society has an 'in-built' political mechanism. But the 'degree of specialization' and the 'formal structuration' may vary significantly in each culture. These differentiated specialization, legitimacy and integrity classified the societies into a linear evolutionary sequence, starting from band society, tribal society, chiefdoms to modern state (Service, 1978). It was Robert Lowie who extricated the classical political anthropology from the unilinear, speculative evolutionism (Ferraro et al., 2010).

\section{Political Anthropology: A Brief Outline From Structure To Agency:-}

As a response to the earlier approach, during 1920s, a differentiated, towards a more formal political anthropology was developed which set to study the older issues but with a newer methodology, i.e. 'ethnography' (Balandier, 1972). The anthropology of politics is intimately related to ethnography, the anthropologists' pride and joy, the discipline's life-blood on which everything else in their craft depends (Vincent, 2002:2). In contrast to the classical evolutionist, this inclusion stigmatized the prominent disparity between 'abstract political structure' and 'on-theground political reality'. The incorporation of ethnographic fieldwork was introduced by Franz Boas and B.K. Malinowski. Though their contributions on political anthropology were rarely acknowledged, both of them engaged in extensive research on political organization in their ethnography. In Anthropology and Modern Life (1962) Franz Boas applied a very conscious comparative anthropological approach to pursue the politically sensitive issues like race, nationalism, criminology and eugenics which further conceptualize a very formative phase of 'critical' and 'reflexive' political anthropology. Whereas Malinowski in Crime and Custom in Savage Society (1970) exerted the 'functionalist legal approach' to study the legal affairs, social order, types of criminal offence and mechanisms of punishment by applying the method of 'participant observation' which further became a prototype for next generation scholars specially political anthropologists engaged in African studies.

Radcliffe-Brown was generally considered as one of the father figures of the formal political anthropology as his structural-functionalism had a more prominent orientation towards the concept of 'political'. He conceptualized society in terms of 'system in equilibrium' where every single institution was the part of the 'whole' structure (Spencer, 2007). It was only in 1940s when political anthropology became a self-evident, full grown branch of anthropology which actively opposed any association with evolutionism and historicism (Asad, 1973). One of the exceptional concerns associated with this time period was the exclusive concentration on the study of colonial Africa which challenged the age old western tradition of anthropological 'field' selection. This British structural functionalist school of thought was internalized within the domain with the decisive work of Fortes and Evans Pritchard, African Political Systems (1940). Within their book they distinguished two types of African political system-'centralized authority' of the 'state society' which was based on administrative organization and 'judicial institute' of 'stateless society' where kinship systems are the modes of socio-political integration and decision 
making authority. The controversies regarding the politics within the 'pre-industrial' societies and the typologies were further increasingly redefined into the work of A. L. Southall, Alur Society (1953) where he challenged the assumption of the disjuncture between the two lineage systems, segmentary and the centralized one.

By the 1950s the static structural-functionalist paradigm was shifted towards a more dynamic 'process approach' as a response to the rapid shrinking of African colony (Barth, 1959; Bailey, 1969; Vincent, 1978). Edmund Leach identified the coexistence of three different political systems within his book, Political Systems of Highland Burma (1954) by analyzing the distribution of power 'between agents and groups of agents'. As the differentiated political systems constitute the 'whole', the 'state of equilibrium' is out of question. There are always the presence of 'conflict, change and contradiction' as the response to the extrinsic and intrinsic pressures within the society. This concept of conflict within the political anthropology was further explored by the 'Manchester school of thought'. Max Gluckman at first in his book, Order and Rebellion in Tribal Africa (1960) further in Custom and Conflict in Africa (1969), developed the notion of 'equilibrium'- which is neither a 'static' nor a 'stable' reality rather it is an perpetual dialectical process where conflicts within one set of relations are absorbed and integrated within another set of relations: cross-cutting loyalties tend to unite the wider society in settling a feud between local groups...apartheid in South Africa, while radically dividing white from black, ultimately unites both groups within themselves (Lewellen, 2003:9). In course of emphasizing 'process and conflict' he added a newer approach to the conflict theory, i.e. individual conscious decision making and choices in 'crisis' (Spencer, 2007). In the cue of Gluckman's 'individualistic situation analysis', Turner in his book Schism and Continuity in an African Society (1957) studied an agent through a succession of social dramas to dismantle the strategic manipulation of agency and structure by social norms and values. Within 1960s and 1970s the concept of 'conflict and social reproduction' were further extensively elaborated by the Marxian approach within the domain of political anthropology (Friedman, 1975; Schneider et al., 1976; Bourdieu, 1977).

\section{Anthropological Shifts And Turns In Politics: The Journey From Stateless To In/Of The State:-}

The framework, and methodology of 'political anthropology' were actually resultant of 'classical anthropology' with a high inclination towards the 'post war-isms', i.e. functionalism, structural functionalism, and marxism. But with the retreat of these grand narratives during the 1980s, there was a 'sudden death' of political anthropology from the centre of anthropological arguments (Spencer, 2007:1). Paradoxically, within the domain of anthropology 'politics' recurred at the moment with the emergence of 'post-structuralism, and post colonial approaches' (Thomassen, 2008). This sudden shift in anthropological discourses conceptualized power in foucauldian mode as diffuse rather than concentrated, embodied and enacted rather than possessed, discursive rather than purely coercive, and constitutes agents rather than being deployed by them, instead of assuming power is 'outside' the individual and beyond 'the state and sovereignty' (Gaventa, 2003:12). This 'development' changes the language of the politics within anthropology and broadens the spectrum of 'political'. Within the discipline it solidified under a new name as 'anthropology of politics'.

Though Radcliffe-Brown while writing the preface of African Political System vehemently discarded 'state' as an issue to be fit for anthropological concern by identifying it as fetishized, mystified and an ideological construct without agency and hence without existence in the phenomenological world (Stepputat et al., 2015:9), anthropology of politics started to rekindle the anthropological focus to study the more 'complex' social settings. Inspired by Abrams (1988), the upcoming ethnographic accounts were progressively dedicated towards the 'trans-local systems of institution, policy and practice' i.e., the state, bureaucracy, markets. The incentive to contextualized the 'local' within 'global' initiated with the famous concept of 'folk-urban continuum' and 'great tradition and little tradition' by Robert Redfield (Redfield, 1941). Within the period between 1960s-1970s the western anthropology came closer to its 'home'. By criticizing the previous anthropological attempt to study the isolated south European 'tribalized' islands, the increased number of ethnographic account on the European complex society transmuted anthropology into more 'political' (Boissevain et al., 1975). With an intense interest in Gramscian conceptualization of 'hegemony and resistance' the anthropologists thematized their concern on political issues at two levels-a) to study the political circumstances and political organization of the settings external to the bureaucratic state-regulation (patron-client relation), and b) the organizations and institutions of the modern bureaucratic state (by correlating different forms of political institutions) (Trouillot, 2001; Wright, 1994; Geertz, 1980). 
From 1980s onwards anthropology of politics has started to shift its focus on the issues like 'ethnicity, nationalism and ethnic-national conflict' (Bowman, 2003). By replacing the previous monolithic construction of kinship study, the newer trend of 'identity politics' goes beyond the boundary of 'nation-state'. It started to incorporate the NGOs, private companies, international organizations like European Union to understand the ideas, imaginaries of the said 'institution' by analyzing the rituals, symbols, identity structuration of the 'subjects and employees' in their everyday life (Herzfeld, 1992; Riles, 2001).

In cue of historians, later anthropology of politics also confronts the issues like the political struggles of the developing countries, decolonization, labour resistance and neo-liberalism under the level of 'subaltern studies' (Ludden, 2002; Guha, 1982). Cohn (1987) within his studies thoroughly discussed the 'localized and particularistic tales' of power relations within the colonial India which gives impetus to the anthropology of politics into further intensive research on post-colonialism, neoliberal nationalism, peasant insurgency, class and gender. Lewellen (1983) termed this newer development within the discipline as study of the 'formal institution of industrial society' by essentially relating it with the 'action of modernization'. By applying the 'world system theory' in Europe and the People without History (1982), Eric Wolf synthesized that over the last century virtually all cultures could be conceptualized relatively to the 'conclave of European capitalism'. Later a number of research (e.g. Scott, 1985) critic the notion of mainstream 'development' by encountering the 'native-as-victim approach' which emphasized the desolation of indigenous culture by the force of 'large scale capitalist' means of production, and their performative resistance, either to maintain their ethnic identity or to create/protect their niche from the encroachment of dominant state.

This subaltern version of 'development' is also within the consistent focus of anthropology of policy which is a part of an overlapping subfield of anthropology, i.e. developmental anthropology/anthropology of development (Shore et al., 1997). The new ethnographic accounts critically focus on the discourses and practices precipitated by the institutional agencies (like states, other governmental institutions, NGOs, multinational and private corporations) while encountering with the local citizen (Ferguson, 1994; Yanow, 1996; Paley, 2002; Mosse, 2001; Murray Li, 2007). It associates anthropology of politics with the political economic approaches to [re]define the 'production, management and redistribution' of material and virtual resources within the neoliberal state (Hart, 1982). According to Escobar (1995), one of the stalwart figures of anthropology, these aided international developments enforce state to regenerate the 'former colonial power structures'.

\section{The Recent Trends And Discussion:-}

Within the recent years, the inception of the feminist wave pushed political anthropology into a new purview. Though in the initial phase it is rarely vocal about 'political', the underline orientations and theorization of the field is tend to analyze the relative power position of women within the society (Lewellen, 2003; Dhakal, 2011). It subsequently challenges the normalization of universal male ascendency, the dominant model for physical evolutions, such as 'man-as-the-hunter' model (Kurtz, 2001). Lately two different schools of thought virtualized the feminist studies in two different ways. One followed the cultural construction and conceptualization of 'gender', while the other based on the Marxian theory, began to critically analyze the historical development of 'gender stratification' (Moghadam, 2005; Maturi, 2003). Later in the era of neoliberal globalization it refocuses on the concept of power as more diffused, locally concentrated and subtly pervaded through every facet of culture and discourse.

In this course, one of the greatest challenges of political anthropology at present is the contradiction and consensus about the 'question of methodology' which makes 'others' skeptical towards its contribution to the larger political discourses globally. While going through the vast literatures concerning political anthropology, the present authors notice that the problem lies within the disciplinary practice of unexplainable abandonment of certain conceptual and theoretical approaches (e.g. complete abandonment of classical and neo-evolutionist approaches), and inadequate attention paid towards the 'offbeat' anthropological works on 'political', like the contributions of René Girard (Fleming, 2004; Wydra, 2008) and Gregory Bateson (Thomassen, 2008). So it demands a 'nonconformist' critical summation of the sub-discipline.

The authors are very much aware that this article only able to explore the frontier of the vast field of research and reflection. Nevertheless at the end of this article we opine that within political anthropology there has an extended scope of interdisciplinary 'politics and policy' study, called as 'global political ethnography'. This emerging field critically throws challenges to its practitioners about- how methodologically the meta-narratives of 'ethnography' 
can be transformed and adapted within these contemporary 'multi-cited' and multidisciplinary researches. However, the present authors hope that the discussion about the varied approaches, theoretical orientations and methodological prospective will broaden the scope for further intensive researches that will widen the conceptualization of the 'political'.

\section{Reference:-}

1. Abrams, P. (1988): Notes on the Difficulty of Studying the State. Journal of Historical Sociology, 1(1): 58-89.

2. Asad, T. (1973): Anthropology and the Colonial Encounter. London: Ithaca.

3. Bailey, F. G. (1969): Stratagems and Spoils: A Social Anthropology of Politics. New York: Schocken Books.

4. Balandier, G. (1972): Political anthropology. New York: Vintage Books.

5. Barth, F. (1959): Political Leadership among the Swat Pathans. London: Athalone.

6. Boas, F. (1962): Anthropology and Modern Life. Reprint, New York: Norton.

7. Boissevain, J., and Friedl, J. (1975): Beyond the Community: Social Process in Europe. The Hague: University of Amsterdam.

8. Bourdieu, P. (1977): Outline of a Theory of Practice. Cambridge: Cambridge University Press.

9. Bowman, G. (2003): Constitutive Violence and the Nationalist Imaginary: Antagonism And Defensive Solidarity in 'Palestine' and 'Former Yugoslavia'. Social Anthropology, 11(3): 37-58.

10. Brennan, G. (2008): Homo Economicus and Homo Politicus: An Introduction. Public Choice, 137(3/4): 429438.

11. Cohn, B. (1987): An Anthropologist among the Historians and Other Essays. Delhi: Oxford University Press.

12. Dhakal, S. (2010): Politics beyond the political sphere: Community Based Organisation and Local Democracy. Silver Jubilee Proceedings of the Department of Sociology/Anthropology, TU, Kathmandu.

13. Dhakal, S. (2011): Political Anthropology and Anthropology of Politics: An Overview. Dhaulagiri Journal of Sociology and Anthropology, 5: 217-234.

14. Engels, F. (1972): The Origin of the Family, Private Property and the State. Reprint, New York: International Publishers.

15. Escobar, A. (1995): Encountering Development: The Making and Unmaking of the Third World. Princeton: Princeton University Press.

16. Ferguson, J. (1994): The Anti-Politics Machine: "Development," Depoliticization and Bureaucratic Power in Lesotho. Cambridge: Cambridge University Press.

17. Ferraro, G., and Andreatta, S. (2010): Cultural Anthropology: An Applied Perspective. Belmont, CA: Wadsworth.

18. Fleming, C. (2004): René Girard: Violence and Mimesis. Cambridge: Polity.

19. Fortes, M., and Evans-Pritchard, E. E. (1940): African Political Systems. Oxford: Oxford University Press.

20. Friedman, J. (1975): Tribes, States and Transformations. In: Bloch M (ed) Marxist analyses and Social Anthropology. London: Malaby Press.

21. Gaventa, J. (2003): Power after Lukes: a review of the literature. Brighton: Institute of Development Studies.

22. Geertz, C. (1980): Negara: The Theatre State in Nineteenth-century Bali. Princeton: Princeton University Press.

23. Gluckman, M. (1960): Order and Rebellion in Tribal Africa. Glencoe: Free Press.

24. Gluckman, M. (1969): Custom and Conflict in Africa. New York: Barnes and Noble.

25. Guha, R. (1982): Writings on South Asian History \& Society. New Delhi: Oxford University Press.

26. Hart, K. (1982): The Political Economy of West African Agriculture. Cambridge: Cambridge University Press.

27. Herzfeld, M. (1992): The Social Production of Indifference: Exploring the Symbolic Roots of Western Bureaucracy. Chicago: The University of Chicago Press.

28. Kurtz, D. V. (2001): Political Anthropology: Paradigms of Power. Boulder: Westview.

29. Leach, E. R. (1954): Political Systems of Highland Burma. Boston: Beacon Press.

30. Lewellen, T. (2003): Political anthropology: an introduction. Westport, CT: Praeger.

31. Lewellen, T.C. (1983): Political Anthropology an Introduction. Massachusetts: Bergin and Garvey.

32. Ludden, D. (2002): Reading Subaltern Studies: Critical History, Contested Meaning, and the Globalisation of South Asia. Delhi: Permanent Black.

33. Maine, H. (1861): Ancient Law, Its Connection with the Early History of Society, and Its Relation to Modern Ideas. London: John Murray.

34. Malinowski, B. (1970): Crime and Custom in Primitive Society. Reprint, London: Routledge.

35. Maturi, E. (2003): Women and the Economy: An Economic Reader. New York: M.E. Sharpe.

36. Moghadam, V. M. (2005): Globalizing Women: Transnational Feminist Networks. Baltimore: Johns Hopkins. 
37. Morgan, L. H. (1877): Ancient Society. New York: Henry Holt.

38. Mosse, D. (2001): People's Knowledge, Participation and Patronage: operations and Representations in Rural Development. In: Cooke B, Kothari U (eds) Participation: The New Tyranny?. London: Zed Books.

39. Murray Li, T. (2007): The Will to Improve: Governmentality, Development, and the Practice of Politics. Durham: Duke University Press.

40. Paley, J. (2002): Towards an Anthropology of Democracy. Annual Review of Anthropology, (31): $469-496$.

41. Redfield, R. (1941): The Folk Culture of Yucutan. Chicago: University of Chicago Press.

42. Riles, A. (2001): The Network Inside Out. Ann Arbor: University of Michigan Press.

43. Salemink, O. (2003): The ethnography of Vietnam's Central Highlanders: A historical contextualization, 18501990. London: Routledge.

44. Schneider, J., and Schneider, P. (1976): Culture and Political Economy in Western Sicily. New York: Academic Press.

45. Scott, J. C. (1985): Weapons of the Weak. New Haven: Yale University Press.

46. Service, E. R. (1978): Profiles in Ethnology. New York: Harper and Row.

47. Shore, C., and Wright, S. (1997): Anthropology of Policy: Critical Perspectives on Governance and Power. London: Routledge.

48. Southall, A. W. (1953): Alur Society. Cambridge: Heffer.

49. Spencer, J. (2007): Anthropology, Politics and the State: Democracy and Violence in South Asia. Cambridge: Cambridge University Press.

50. Stepputat, F., and Larsen, J. (2015): Global political ethnography: A methodological approach to studying global policy regimes. DIIS, Working Paper No. 1.

51. Thomassen, B. (2008): What Kind of Political Anthropology?. International Political Anthropology, 1(2): 263274.

52. Trouillot, M. R. (2001): The Anthropology of the State in the Age of Globalization: Close Encounters of the Deceptive Kind. Current Anthropology, 42(1): 125-138.

53. Turner, V. (1957): Schism and Continuity in an African Society. Manchester: Manchester University Press.

54. Vincent, J. (1978): Political Anthropology: Manipulative Strategies. Annual Review of Anthropology, 7: 175194.

55. Vincent, J. (2002): The Anthropology of Politics: A Reader in Ethnography, Theory, and Critique. Oxford: Blackwell.

56. Wolf, E. R. (1982): Europe and the People Without History. Berkley: University of California Press.

57. Wright, S. (1994): The Anthropology of Organizations. London: Routledge.

58. Wydra, H. (2008): Towards a new Anthropological Paradigm: The Challenge of Mimetic Theory. International Political Anthropology, 1(1): 161-174.

59. Yanow, D. (1996): How Does a Policy Mean?: Interpreting Policy and Organizational Actions. Washington: Georgetown University Press. 